Tersedia online di: http://ejournal-balitbang.kkp.go.id/index.php/jkpi
e-mail:jkpi.puslitbangkan@ gmail.com
JURNAL KEBIJAKANPERIKANANINDONESIA
Volume 12 Nomor 2 November 2020
p-ISSN: 1979-6366
e-ISSN: 2502-6550
Nomor Akreditasi Kementerian RISTEK-BRIN: 85/M/KPT/2020

\title{
STATUS PERIKANAN BELIDA (CHITALA LOPIS) DI PROPINSI RIAU DAN STRATEGI PENGELOLAANNYA SECARA BERKELANJUTAN
}

\section{THE STATUS OF CLOWN KNIFEFISH FISHERIES IN RIAU PROVINCE AND IT'S MANAGEMENT STRATEGY THROUGH SUSTAINABILITY}

\author{
Estu Nugroho*1, Raden Roro Sri Pudji Sinarni Dewi², Aisyah¹, Bambang Priono \\ ${ }^{1}$ Pusat Riset Perikanan, Gedung Balitbang KP II. JI. Pasir Putih II, Ancol Timur, Jakarta Utara, Indonesia \\ ${ }^{2}$ Balai Riset Perikanan Budidaya Air Tawar dan Penyuluhuan, Jl. Sempur No.1, Bogor, Jawa Barat-16129, Indonesia \\ Teregistrasi I tanggal: 02 April 2020; Diterima setelah perbaikan tanggal: 23 November 2020; \\ Disetujui terbit tanggal: 29 Desember 2020
}

\begin{abstract}
ABSTRAK
Berbagai ancaman terhadap populasi belida di alam, seperti rendahnya nilai indikator ketersediaan induk di alam (15\%), tingkat pemanfaatan yang tinggi, dan beberapa aturan perlindungan sebagai bukti adanya kekhawatiran kepunahan belida, menunjukkan perlunya upaya pelestarian tertentu menuju pengelolaan belida yang berkelanjutan. Kajian bertujuan untuk memformulasikan upaya menjaga keberlanjutan populasi belida di alam dan mendukung upaya peningkatan produksi, dengan melihat kondisi terkini perikanan belida baik dari aktifitas penangkapan maupun budidaya. Analisis sederhana dilakukan terhadap produksi dan hasil tangkapan belida di wilayah Propinsi Riau serta perkembangan kegiatan budidaya. Hasil menunjukan bahwa terdapat beberapa hal positif yang mendukung pemanfaatan belida sebagai komoditi budidaya. Dari sisi penangkapan, kontribusi belida terhadap total produksi perikanan perairan darat baik secara lokal (Riau) maupun nasional adalah relatif kecil, namun sampai dengan saat ini kebutuhan pasar dan industri lokal Riau hingga luar Riau masih bisa dipenuhi. Di samping itu, terdapat mekanisme pasar yang memberlakukan harga tinggi pada ukuran besar serta keberadaan lubuk larangan sebagai daerah yang dilindungi. Hal positif lainnya adalah latar belakang genetik yang memungkinkan pemanfaatan benih dan indukan dari lokasi Kampar dan Palembang untuk keperluan pemulihan di alam. Serta telah dikuasainya teknologi pemijahan belida dalam lingkungan terkontrol di luar habitat alaminya. Di sisi lain masih terdapat kondisi yang tidak mendukung keberlanjutan sumber daya ikan belida antara lain kondisi alami habitatnya yang sudah mengalami degradasi. Degradasi yang lebih nyata terlihat diduga lebih cepat berdampak jika dibandingkan dengan upaya pemulihannya. Budidaya diyakini mampu menjembatani percepatan pemulihan tersebut guna meningkatkan produksi ikan belida dalam hal ini.
\end{abstract}

Kata Kunci: Belida; budidaya; Chitala lopis; genetik; strategi pengelolaan

\begin{abstract}
Various threats occurred to clown knifefish (belida) populations in wild nature, such as the low value of indicators for the availability of broodstock in nature (15\%), high utilization rates, and several protection regulations as evidence of clown knifefish extinction concerns, indicate the need for certain conservation efforts towards sustainable clown knifefish management. The study aims to formulate efforts to maintain the sustainability of clown knifefish populations to population also the needs in increasing production, by looking at the current conditions of clown knifefish fisheries both from fishing and aquaculture activities. A simple analysis was carried out on the production and catch of clown knifefish in Riau Province as well as aquaculture. The results show that there are several positive things that support the use of clown knifefish as an aquaculture commodity. In terms of fishing, the contribution of clown knifefish to total inland fishery production both locally (Riau) and nationally is small relatively, however until now the market and industrial needs of local Riau to outside Riau can still be met. In addition, there is a market mechanism that imposes a high price on large sizes as well as the existence of 'lubuk larangan' as a protected area. Other positive is the
\end{abstract}

Korespondensi penulis:

e-mail: icha saraimanette@yahoo.com

Telp.+62 816-5491-9449 
genetic background that allows the use of seeds and broodstock from Kampar and Palembang locations for recovery purposes in nature. Also technological developments of spawning in a controlled environment outside their natural habitat. On the other hand, there is unsupported condition to the sustainability of clown knifefish resources, including the degradation of habitat. The more obvious degradation is seen having a faster impact than the recovery effort. Aquaculture is believed to be able to bridge the acceleration of the recovery in order to increase the production of clown knifefish in this case.

Keywords: Aquaculture; Chitala lopis; clown knifefish; genetic; spawning technology

\section{PENDAHULUAN}

Ikan belida (Chitala lopis) berasal dari family Notopteridae (Kottelat et al., 1993; Kottelat \& Whitten, 1996), merupakan jenis yang bernilai ekonomis (relatif mahal), dengan sebaran geografis yang terbatas yaitu di wilayah India, Myanmar, Thailand dan Indo-Cina, Malaysia serta Indonesia (Froese \& Pauly, 2013). Di Indonesia sendiri dijumpai di Pulau Sumatra, Jawa dan Kalimantan (Kottelat et al., 1993). Jika dilihat dari jenis yang dilindungi dalam Permen LHK nomor 20 tahun 2018, belida di Indonesia meliputi belida Borneo (Chitala borneensis), belida Sumatera (Chitala hypselonotus), belida lopis (Chitala lopis), dan belida Jawa (Notopterus notopterus)

Belida merupakan jenis unggulan di beberapa daerah di Indonesia, seperti Jambi dan Sumatera Selatan (Rahayuni, 2005). Pemanfaatannya selain sebagai ikan hias dan sumber protein juga sebagai bahan baku olahan kerupuk dan empek-empek (Ondara \& Dharyati et al., 1993; Haryono, 2008). Belida yang berasal dari sungai dan rawa banjiran di Riau selain dimanfaatkan di tingkat lokal juga oleh pemanfaat dari luar Riau seperti Palembang. Kebutuhan belida oleh pasar Palembang di tahun 2019 bahkan mencapai 2 ton per bulan (Nugroho et al., 2019a). Data tersebut diduga masih underestimate karena belum memperhitungkan pengumpul yang langsung menjemput hasil tangkapan ke lokasi. Sukemi et al. (2016) mencatat bahwa serapan komoditi belida oleh pasar adalah sebesar 135-150 $\mathrm{kg} / \mathrm{hari}$ atau sekitar 4 ton per bulan. Tingginya permintaan pasar terhadap komoditi belida juga tampak pada arus perdagangan via online produk empek-empek dari Palembang yang mencapai 7-8 ton per bulan (Tabloid Desa, 2017). Tidak hanya di Indonesia, pemanfaatan pasca panen belida (jenis Chitala ornata) juga dilakukan di Filipina, yang mana belida dijadikan sebagai bahan baku produk olahan seperti nugget, kikiam dan siomai (Tamayo \& Bunal, 2018).

Di beberapa wilayah sebarannya, belida menunjukan tren degradasi seperti produksi di Propinsi Riau yang menurun drastis (Wibowo et al., $2010^{a}$ ), populasi yang sudah jarang dijumpai di aliran Sungai Brantas - Jawa Timur (Isroni, 2019) dan di Jambi (Suprapto, 2018). Menurunnya ketersediaan di alam diduga karena eksploitasi yang intensif, fekunditas yang rendah (terkait dengan strategi reproduksi) dan pemangsaan oleh jenis lain serta relung yang relatif sempit (Pollnac \& Malvestuto, 1991; Adjie et al., 1999; Sunarno et al., 2006; Haryono, 2008; Sunarno et al., 2009; Wibowo et al., 2010 $)$.

Pemanfaatannya yang tinggi yang didukung oleh peluang ketersediaan yang masih relatif ada, memerlukan kajian khusus berbasis data dan informasi ilmiah. Selain untuk menjaga keberlanjutan populasi belida di alam terutama yang ada di Propinsi Riau, terdapat peluang lainnya seperti pengembangan budidaya ikan belida untuk mendukung upaya peningkatan produksi. Melalui kajian ini diharapkan informasi tingkat pemanfaatan belida dapat diketahui dengan melihat kondisi terkini perikanan belida baik dari aktifitas penangkapan maupun budidaya.

\section{DUKUNGAN DATA DAN INFORMASI ILMIAH}

Proses pengumpulan data dan informasi dilakukan pada periode Januari - Juli 2019, dengan melakukan pengumpulan data sekunder dan survei lapangan secara langsung di beberapa sentra belida, seperti Kabupaten Kampar dan Kab. Pelalawan, Propinsi Riau, yaitu BBI Sipungguk (Kec. Salo), Tanjung Alai (Kec. XIII Koto Kampar) dan Desa Langgam (Kec. Langgam) (Gambar 1). Data primer yang digunakan berasal dari beberapa pengumpul lokal. Beberapa data tahun sebelumnya diperoleh dari hasil kajian tahun 2009 oleh Lestari (2010) dan tahun 2016. 


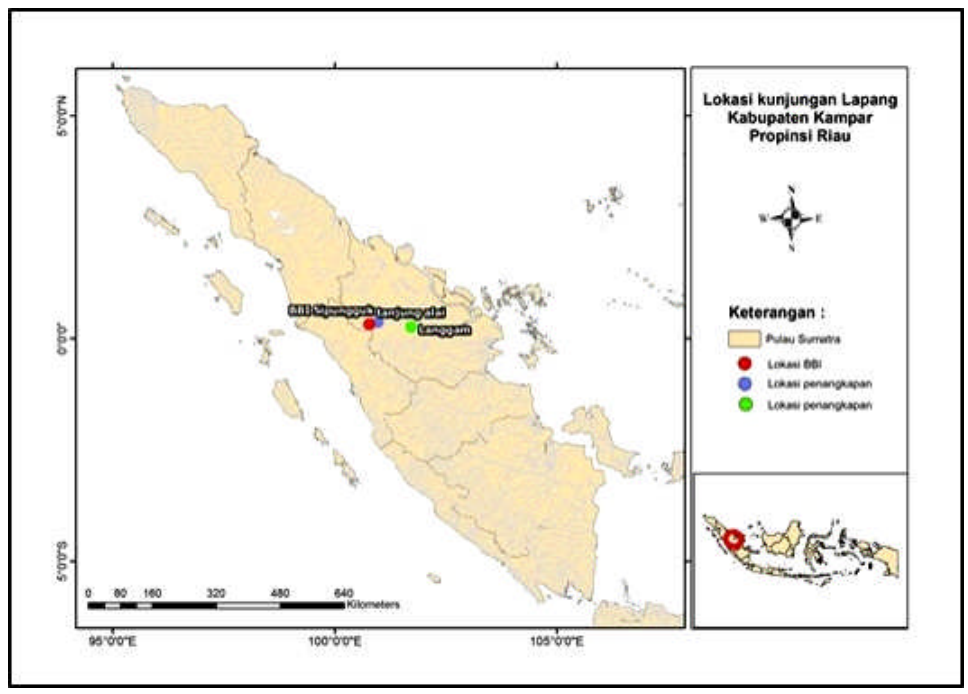

Gambar 1. Lokasi kajian tahun 2019.

Figure 1. Study area in 2019.

\section{STATUS PERIKANAN TANGKAP}

Analisis sediaan induk di alam melalui metode Spawning Partial Ratio (SPR) menunjukan bahwa jumlah populasi belida yang tergolong indukan hanya sekitar $15 \%$ dari total estimasi jumlah populasi belida di Sungai Kampar. Hal tersebut menandakan adanya ancaman terhadap proses rekrutmen alami. Pengamatan ini didukung oleh hasil analisis terhadap data panjang ikan dan tingkat kematangan gonad ikan belida yang tertangkap oleh nelayan di wilayah Riau tahun 2016 (Kartamihardja et al., 2016 ${ }^{\text {a) }}$.

Pengamatan terhadap hasil tangkapan nelayan di Sungai Kampar menunjukan terdapat 20 jenis ikan yang umumnya tertangkap dan bernilai ekonomis (harga relatif tinggi) termasuk di dalamnya adalah belida (Nugroho et al., 2019a). Keberadaan belida sebagai hasil tangkapan bergantung pada jenis alat tangkap yang digunakan. Belida tertangkap dengan alat tangkap yang bersifat perangkap seperti lukah dan sempirai atau yang dikenal dengan bubu (traps) serta pancing. Pada umumnya terdapat 1-13 ekor belida yang tertangkap dalam satu alat tangkap. Hasil tangkapan belida dengan pancing relatif lebih banyak jika dibandingkan dengan bubu. Alat tangkap seperti bubu dan pancing bersifat selektif dengan target penangkapan jenis ikan tertentu dan bersifat ramah lingkungan. Namun permasalahan sebenarnya bukan pada jenis alat tangkap yang digunakan tersebut tetapi jumlahnya yang hampir tidak dapat diidentifikasi karena bersifat skala kecil dan tersebar luas di titiktitik tertentu di sepanjang Sungai Kampar.

Produksi belida di Riau tahun 2003 dan 2007 menunjukan penurunan yang signifikan yaitu dari 50,2 ton menjadi 7,6 ton (DKP DT I Riau, 2003 dan 2007 dalam Wibowo et al., 2010 ${ }^{a}$ ). Sementara data tahun 2006-2015 menunjukan bahwa kisaran produksi belida dari Propinsi Riau adalah 24-185 ton per tahun. Kisaran tersebut meliputi $0,17-1,33 \%$ dari total perikanan tangkap perairan darat di Propinsi Riau. Jika dibandingkan dengan produksi belida secara nasional, produksi belida di Propinsi Riau berkontribusi hanya sebesar 1,28-6,62\% (Gambar 2). Kontribusi belida yang relatif kecil tidak sebesar jenis dominan lainnya seperti patin, lais, baung dan udang galah. Kontribusi yang relatif kecil tidak serta merta menunjukan tingkat eksploitasi yang rendah, namun lebih kepada sistem pendataan yang belum meliputi semua hasil tangkapan ikan belida dari alam. Kondisi tersebut juga ditunjukan oleh tren produksi belida yang fluktuatif dan dinamis serta kontinuitas dalam mensuplai kebutuhan pasar baik lokal maupun luar Riau seperti Palembang.

Demikian hal-nya dengan ukuran bobot belida yang dijadikan sampel pengamatan, data tersebut tidak secara jelas menunjukkan gambaran kecendrungan penurunan populasi. Tren hasil tangkapan tahun 2009 dan 2016 sama-sama didominasi oleh selang ukuran bobot $1 \mathrm{~kg}$ (Gambar 3). Sebaran frekuensi ukuran berat $1,5-11 \mathrm{~kg}$ dari tiga tahun pengamatan tersebut kemudian merata pada kisaran tidak lebih dari $20 \%$. Jumlah sampel yang lebih banyak tahun 2019 memungkinkan dijumpainya ukuran yang lebih besar $(11 \mathrm{~kg})$. Bobot per jenis kelamin juga turut mempengaruhi berat total tangkapan, dimana belida betina relatif lebih besar dibandingkan ikan belida jantan. Hal tersebut juga didukung oleh beberapa kajian lainnya yang menyatakan bahwa pada umumnya belida betina berukuran lebih panjang dari 
pada jantan, demikian hal-nya dengan bobot (Sunarno, 2002; Cholik et al., 2005 Sarkar et al. (2006). Jumlah tangkapan belida juga turut dipengaruhi oleh musim penangkapan. Hasil tangkapan ikan di Waduk Koto Panjang -Tanjung Alai menunjukkan bahwa selama bulan Januari-April 2019 berkisar antara 396,6-689,5 kg, dan 7,97\% - 31,45\% diantaranya adalah ikan belida. Pada musimnya yaitu bulan Juli, hasil tangkapan belida relatif tinggi yaitu mencapai $61,64 \%$ dari total hasil tangkapan $(537,5 \mathrm{~kg})$.

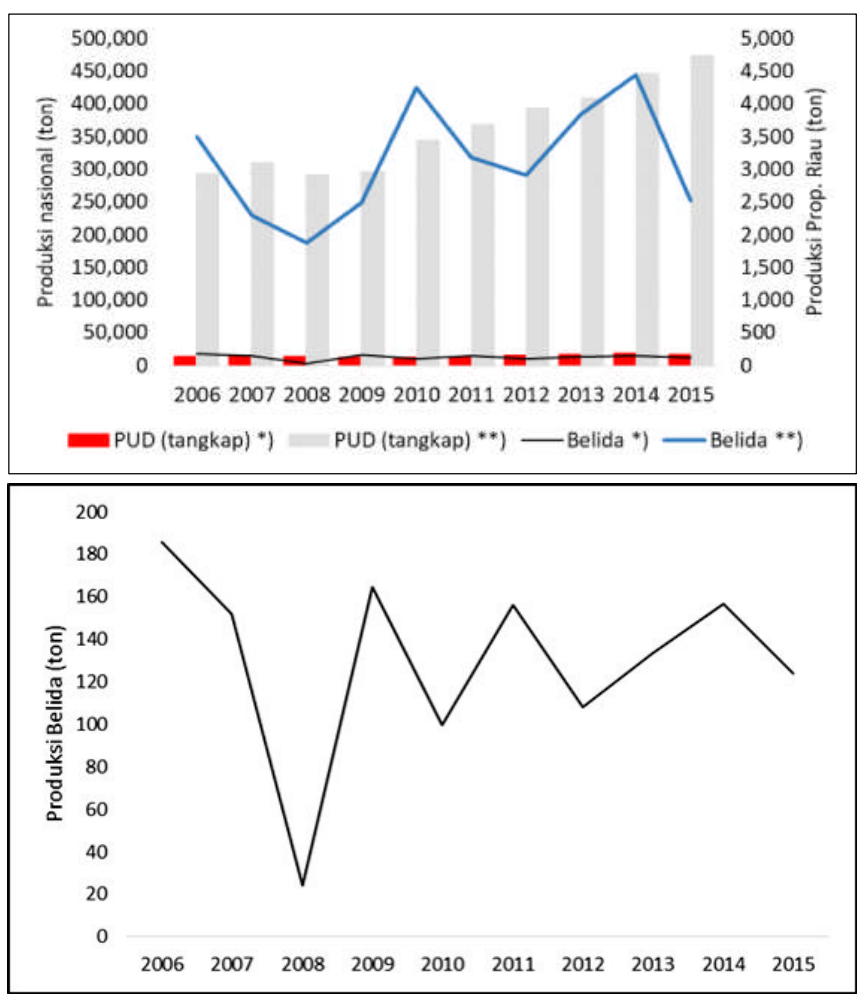

Ket. : $\quad$ *) Prop. Riau; ${ }^{* *}$ nasional

Sumber: $\quad$ Diskanlut Riau, 2015; DJPT, 2015; BAPPEDA \& BPS, 2006 \& 2007; BPS, 2008-2015

Gambar 2. Produksi belida terhadap produksi total perikanan perairan darat tahun 2006-2015 (atas), cuplikan produksi belida di Propinsi Riau (bawah).

Figure 2. Production of clown knifefish against total production of inland fisheries in 2006-2015 (above), snapshot clown knifefish production in Riau Province (below).

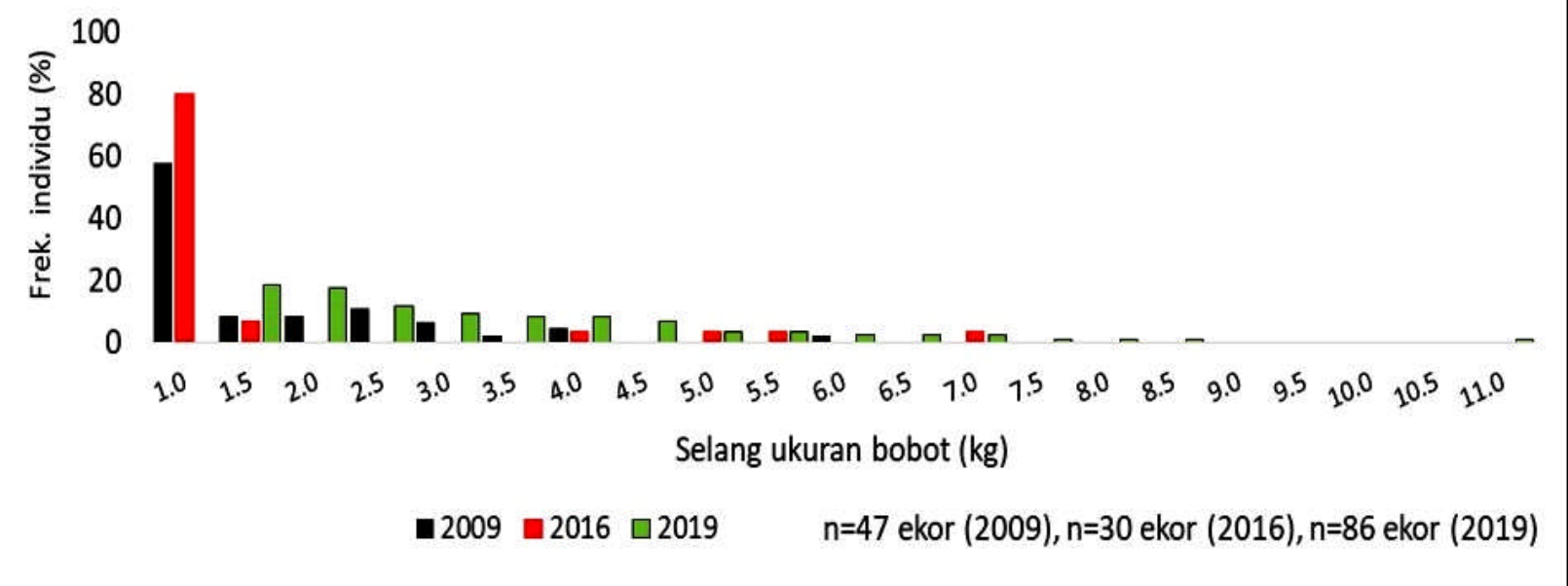

Sumber Data: Lestari, 2010; Kajian ini tahun 2016 dan 2019

Gambar 3. Sebaran ukuran bobot belida periode pengamatan tahun 2009, 2016 dan 2019.

Figure 3. Weight distribution at observation periods of 2009, 2016 and 2019 (primary data). 
Pada umumnya puncak musim penangkapan ikan di perairan darat termasuk di Riau berlangsung saat air menjelang naik dan atau menjelang surut. Merona \& Vigouroux (2006) menyatakan bahwa aktivitas penangkapan dipengaruhi oleh cara atau metoda penangkapan yang digunakan. Aisyah et al. (2018) dalam kajiannya menyatakan bahwa gambaran mengenai periode penangkapan ditentukan oleh tingkah laku ikan terhadap faktor iklim dan habitat serta besar kecilnya magnitude draw down (amplitudo yaitu antara kondisi muka air dalam keadaan surut dan pasang/tinggi; atau periode saat air surut ke kondisi pasang atau sebaliknya). Keseluruhan faktorfaktor tersebut terkait dengan peluang tertangkapnya ikan, sehingga dapat dipahami adanya perbedaan informasi yang diperoleh di lapangan yang sebenarnya adalah magnitude draw down, seperti nelayan Pulo Simo (Riau) yang menyatakan bahwa belida banyak tertangkap saat air dalam keadaan surut, sementara nelayan di Desa Langgam (Kabupaten Pelalawan) menyatakan belida banyak tertangkap saat kondisi air tinggi menjelang surut (Nugroho et al., 2019a).

Di sisi lain kondisi lingkungan habitat yang alami sebenarnya sudah cukup mendukung keberlanjutan hidup belida, yaitu rawa bervegetasi dengan sirkulasi yang lancar (Vidhtayanon, 2005). Sungai Kampar merupakan ekosistem rawa banjiran yang dicirikan oleh fluktuasi air antara musim kemarau dan penghujan yang bervariasi sepanjang tahun. Heterogenitas habitat secara spasial ditunjukan oleh keragaman luas rawa banjiran di sekitar sungai Kampar. Kajian khusus mengenai jenis dan kerapatan tanaman air dilakukan oleh Fazli et al. (2013) dan Nurmaini et al. (2012), di salah satu danau oxbow di Desa Buluh Cina, Kabupaten Kampar dan Sungai Segati di Kecamatan Langgam, pertemuan Sungai Kampar Kanan dan Kampar Kiri. Danau maupun sungai tersebut merupakan bagian dari aliran Sungai Kampar, dengan tanaman air yang berperan sebagai tempat berlindung. Kondisi tersebut dimanfaatkan oleh ikan belida sebagai habitatnya karena bentuk tubuh (ekomorfologi) yang pipih (Haryono, 2008). Kajian mengenai preferensi habitat bagi belida telah dilakukan oleh Adjie \& Utomo (1994), Sunarno \& Syamsunarno (2015) dan Sunarno et al. (2015), dimana keberadaan tonggakan kayu dan tanaman air menjadi pelindung dan tempat penempelan telur, serta pengaruh naungan yang diduga berpengaruh terhadap pematangan telur. Hal yang sama dinyatakan oleh Talwar \& Jhingran (1991), bahwa belida memerlukan vegetasi solid yang terendam air sebagai tempat menempelnya telur.

Namun demikian, degradasi lingkungan telah terjadi di Sungai Kampar. Sungai Kampar sejak tahun
2012 sudah teridentifikasi sebagai sungai tercemar ringan (BLH Riau, 2012 dalam Aisyah, 2019). Sumber bahan pencemar Sungai Kampar berasal dari perkebunan pertanian, industri pulp and paper serta pertambangan emas. Hasil evaluasi kualitas Sungai Kampar dari 2014 sampai 2018 menunjukan bahwa mayoritas titik pantau mengalami pencemaran berat (DLHK Riau, 2018). Selama periode 4 tahun tersebut, Sungai Kampar hanya memenuhi baku mutu air kelas III (tidak kelas I dan II sebagaimana berdasarkan Keputusan Gubernur Riau nomor 23/2003, tentang peruntukan dan baku mutu air Sungai Kampar). Parameter dominan yang mengindikasikan penurunan kualitas air Sungai Kampar di beberapa titik pantau adalah dissolved oxygen (DO), biological oxygen demand (BOD), chemical oxygen demand (COD), klorin bebas, fecal coli dan total fosfat (DLHK Riau, 2018). Parameter dominan di beberapa titik pantau lain adalah TSS, besi dan total coliform (DLHK Riau, 2018). Kondisi ini akan dapat mengancam keberadaan ikan belida terutama pada lokasi yang masih terdapat cukup banyak ikan belida seperti di waduk PLTA Koto Panjang dan Tanjung Anai.

\section{STATUS PERIKANAN BUDIDAYA}

Sebaliknya, dari sisi perikanan budidaya baik di Riau maupun di Indonesia, belida tidak secara tersurat dinyatakan sebagai komoditas budidaya sebagaimana gurame, mas, udang vaname. Tersirat bahwa budidaya belida belum berkembang. Budidaya ikan dari jenis karnivor terhalang oleh karakter biologi jenis ikannya (laju pertumbuhan yang lambat dan behavioursebagai predator) serta kebutuhan kondisi lingkungan habitat yang spesifik (air mengalir dan teraerasi dengan baik) yang kemudian mempengaruhi jumlah padat tebar dan nilai balik secara ekonomi di tiap periode budidaya (Funge-Smith et al., 2012).

Demikian hal nya dengan kajian pendukung, yang sejauh ini masih mengarah pada pemantapan dan penguasaan teknologi yang menjadi tantangan pembudidaya selama ini, seperti pemijahan. Telah dilakukan upaya pemijahan alami ikan belida yang berasal dari Sungai Kampar, Riau, melalui media kolam tanah ukuran $1.000 \mathrm{~m}^{2}$ di daerah Palembang, Sumatera Selatan (Nugroho et al., 2019 ). Dari kajian tersebut diperoleh gambaran bahwa nilai faktor kondisi relatif $(\mathrm{Kn})$ induk dan benih ikan belida yang dibudidayakan memiliki karakter pertumbuhan yang sama dengan yang ada di alam, yaitu tidak gemuk. Faktor ketersediaan makanan ditegaskan juga sebagai faktor penghambat lainnya dalam budidaya belida.

Ikan belida dapat dipijahkan secara alami maupun buatan. Pada pemijahan alami, kolam dilengkapi 
substrat berupa lempengan kayu sebagai tempat penempelan telur ikan. Pemijahan secara alami yang dilakukan di kolam tanah dengan memasangkan 20 ekor induk betina dan 15 ekor induk jantan secara massal, yang kemudian menghasilkan benih ikan belida sebanyak 1.205 ekor dengan ukuran rata-rata panjang total $3,4 \mathrm{~cm}$ dan bobot tubuh $0,4 \mathrm{~g}$ (Dewi et al., 2019). Hasil penelitian Haniffa et al. (2004), yang memijahkan 50 pasang induk jantan dan betina menghasilkan 445 ekor benih dengan ukuran antara $3,4 \pm 0,3 \mathrm{~cm}$ dan bobot $0,45 \pm 0,05 \mathrm{~g}$ selama 1 tahun pemeliharaan induk. Yanwirsal et al. (2017) mencatat bahwa jumlah telur yang dihasilkan secara alami oleh induk ikan belida adalah berkisar antara 25 hingga 225 butir/induk. Sedangkan Lestari (2010) mendapatkan bahwa jumlah telur induk ikan belida berkisar antara 442 - 11.972 butir. Larva ikan belida berumur 25-30 hari telah berubah bentuk menjadi benih dengan ukuran 2,7 $\pm 0,05 \mathrm{~cm}$ (Srivastava et al., 2012).

Upaya lainnya dalam meningkatkan produktivitas ikan belida adalah pengembangan teknologi budidaya melalui penggunaan induksi hormon dalam mempercepat proses maturasi (Setijaningsih et al., 2018). Dengan sampel belida yang berasal dari Cisalak, Kabupaten Subang dan Kampar, Kabupaten Kampar, diperoleh hasil yaitu persentase derajat pembuahan yang terbilang tinggi $(86,7 \%)$ dan lama penetasan yang relatif lebih cepat $(7$ jam setelah dipijahkan), jika dibandingkan dengan kajian-kajian sebelumnya. Beberapa karakter biologi reproduksi belida hasil pemijahan terangkum dalam Tabel 1 berikut.

Tabel 1. Karakter biologi reproduksi ikan belida hasil pemijahan dengan induksi hormon HCG dan LHRHa Table 1. Biology character of clown knifefish that spawned by hormone HCG and LHRHa induction

\begin{tabular}{lcc}
\hline \multicolumn{1}{c}{ Parameter } & Satuan & Hasil Pengamatan \\
\hline Waktu laten pemijahan & jam & $13-15$ \\
Fekunditas & butir & $225-932$ \\
Diameter telur & $\mathrm{mm}$ & $3.2-3.8$ \\
Derajat pembuahan & $\%$ & $21-40$ \\
Derajat penetasan & $\%$ & $56-75$ \\
Panjang larva & $\mathrm{cm}$ & $1.7-1.9$ \\
Bobot larva & $\mathrm{g}$ & $0,0375-0,0379$ \\
Sintasan & $\%$ & $30-50$ \\
\hline
\end{tabular}

Sumber: Setijaningsih et al., 2018

Pembenihan ikan belida dibagi dalam beberapa tahap disesuaikan dengan ukuran ikan dan jenis pakan yang diberikan. Hasil penelitian Dewi et al. (2019) menunjukkan bahwa pada pemeliharaan benih menggunakan ukuran awal $3,4 \mathrm{~cm}$ di akuarium selama 30 hari dengan kepadatan 45 ekor/90L memberikan laju pertumbuhan bobot sebesar $3,1 \%$ /hari dengan sintasan $96,7 \pm 1,33 \%$. Pemeliharaan lanjutan selama dua bulan yang dilakukan dalam akuarium dengan menggunakan jenis pakan berbeda (cacing tubifex dan pakan buatan) menghasilkan pertumbuhan bobot tertinggi terdapat pada benih yang diberi pakan cacing tubifex sebesar $2 \%$ /hari dengan sintasan $29 \pm 3,42$ $\%$. Pemeliharaan benih ukuran $4,9 \mathrm{~cm}$ dalam waring yang diletakkan dalam kolam tanah menghasilkan pertumbuhan dan sintasan yang lebih tinggi jika dibandingkan dalam akuarium. Padat tebar terbaik adalah 10 ekor $/ \mathrm{m}^{2}$ dengan laju pertumbuhan bobot $2,6 \%$ per hari dengan tingkat sintasan sebesar $77,3 \%$. Sedangkan pembesaran ikan belida dapat dilakukan dalam waring atau kolam. Hasil penelitian Dewi et al. (2019) menunjukkan bahwa pembesaran benih dalam waring dengan ukuran tebar $8-9 \mathrm{~cm}$ selama 2 bulan menghasilkan pertumbuhan bobot yang lebih tinggi pada benih yang diberi pakan cacing tubifex $(1,3 \% /$ hari) dibandingkan dengan pakan buatan $(0,6 \% /$ hari $)$ dan campuran pakan buatan + cacing tubifex $(1,0 \%)$ hari).

Selain upaya pemijahan dalam lingkungan terkontrol, teknologinya, pembenihan dan pembesaran, kajian rasio atau nisbah kelamin (sex ratio) dalam kegiatan budidaya turut mendukung keberlanjutan populasi belida. Dewi et al. (2019) dalam kajiannya menyatakan bahwa rasio jantan dan betina sebesar $1: 1,3$ lebih banyak menghasilkan benih jika dibandingkan dengan rasio $1: 1$ (Haniffa et al., 2004). Sementara selama periode kajian ini diperoleh rasio jantan dan betina belida yang tertangkap adalah 0,51 : 0,49 atau 1:1. Dominansi jantan juga dinyatakan dalam Azadi et al. (1994), Sarkar et al. (2006) Lestari (2010), dan Santoso (2009) memperoleh hasil sebaliknya yaitu rasio jantan dan betina adalah $1: 2$. Kajian rasio atau nisbah kelamin (sex ratio) berfungsi sebagai penentu sistem kawin dan tingkah laku pemijahan. Dengan melihat perbandingan kajian dari budidaya dan kondisi rasio kelamin di alam, ketersediaan indukan betina di alam saat kajian diduga tidak terlalu mendukung keberhasilan dalam mengasilkan benih di perairan alami (selain 
permasalahan jumlah sampel yang kemungkinan belum mewakili). Informasi-informasi dan kajian terkait hal tersebut diduga masih terbatas. Keterbatasan informasi pada aspek reproduksi lainnya seperti periode pemijahan serta fekunditas juga terjadi pada budidaya belida (Chitala chitala) di India (Mitra et al., 2018).

Latar belakang genetik dari suatu populasi merupakan aspek lain yang mempengaruhi keberhasilan upaya budidaya. Informasi tentang hal ini akan sangat bermanfaat untuk keberlangsungan keberadaan populasi ikan belida dan kemampuan adaptasinya terhadap lingkungan budidaya. Pengujian karakteristik genetik dilakukan kembali untuk memperkuat kajian ini. Panjang nukleoida Cytochrome Oxidase Subunit I atau COI (Bagian DNA yang umum digunakan sebagai barcoding) yang berhasil disekuensing dari dua populasi ikan belida (Kampar dan Palembang) adalah berkisar $683 \mathrm{bp}$. Pembacaan gen $\mathrm{CO} 1$ menghasilkan persentase basa nukleotida yang berbeda. Adapun proporsi basa penyusunnya masing-masing adalah basa $A$ mempunyai nilai $27,95 \%$, basa $\mathrm{G}$ berkisar antara $17,44 \%$, basa $T$ sebesar 28,67 dan basa $C$ dengan persentase sebanyak 25,94\% (Nugroho et al., 2019º).

Setelah penjajaran dengan menggunakan sampel dari GenBank, dapat diketahui bahwa ikan belida mempunyai tingkat kemiripan atau similaritas sebesar 99-100\% dengan data GenBank Chitala lopis. Hal ini menunjukkan bahwa belida di sungai Kampar dan Palembang merupakan individu dari jenis Chitala lopis. Perbedaan antara sampel yang diamati adalah lebih bersifat variasi intraspesifik. Contoh hasil sekuensing tertera pada Gambar 4. Latar belakang genetik ini memungkinkan pemanfaatan benih dan indukan dari kedua lokasi tersebut pada saat diperlukan untuk kegiatan pemulihan di alam.

Hasil yang sama juga terdapat dalam Wibowo (2012) melalui kajian genetik belida dari Riau menunjukan hasil bahwa terdapat integritas genetik atau perbedaan genetik antara sampel dari Waduk Kotopanjang dengan sampel dari Sungai Kampar, namun jarak genetik (ukuran keragaman genetik) menunjukan kemiripan. Sementara dengan asal sampel dari beberapa lokasi seperti Sungai Indragiri Hilir - Riau, Sungai Mahakam - Kalimantan Timur, Sungai Musi - Sumatera Selatan dan Sungai Penyak - Bangka diperoleh hasil adanya variasi genetik diantara spesies ikan belida baik dengan ikan belida di luar Indonesia maupun diantara sungai-sungai di Indonesia atau berdasarkan gen COI mtDNA diperoleh setidaknya 13 situs bervariasi pada kelompok ikan belida (Wibowo, 2014).

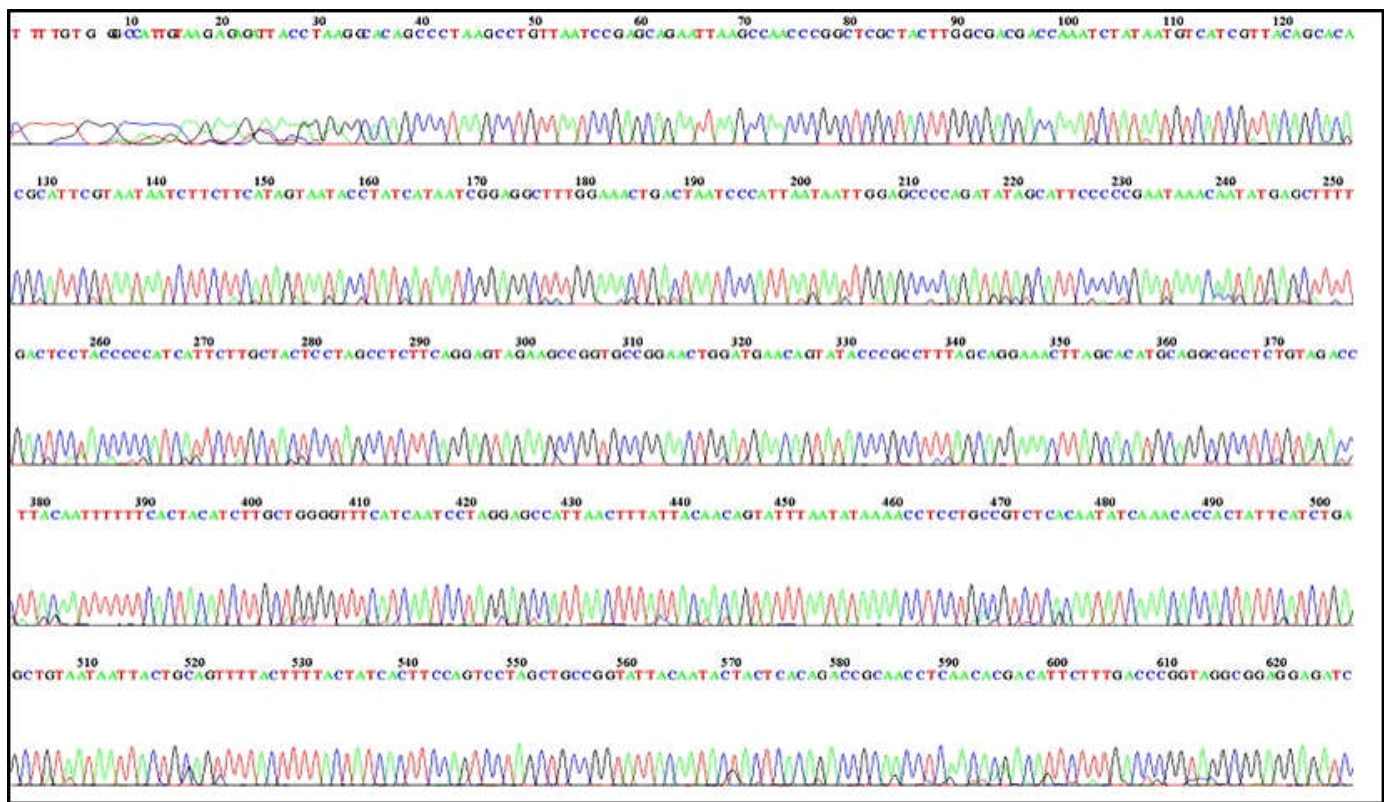

Gambar 4. Hasil Sekuensing pada daerah Mt DNA CO-I sampel dari Palembang dan Sungai Kampar-Riau. Figure 4. Sequencing result of Mt DNA CO-I for sample from Palembang-South Sumatra and Kampar RiverRiau.

Berdasarkan kriteria level domestikasi Teletchea \& Fontaine (2014), teknologi budidaya ikan belida yang dihasilkan dari penelitian ini dapat dikategorikan masuk ke dalam level 2 , yaitu induk masih diperoleh dari alam dan diberi pakan berupa ikan kecil, pemijahan sudah dapat dilakukan dalam lingkungan 
terkontrol di luar habitat alaminya, benih dapat memanfaatkan pakan buatan untuk menunjang kelangsungan hidup dan pertumbuhannya. Domestikasi merupakan upaya untuk membudidayakan ikan yang berasal dari alam ke dalam wadah terkontrol sehingga perkembangbiakan dan pemberian pakannya dapat lebih terkontrol dan memberikan keuntungan bagi manusia (Teletchea \& Fontaine, 2014). Pada ikan, domestikasi diartikan seluruh siklus hidup ikan dapat berlangsung dalam wadah budidaya yang dimulai dari telur, larva, juvenil, sampai menjadi induk, sehingga diperlukan manajemen induk, larva, dan juvenil. Dalam proses domestikasi, beberapa kendala yang umumnya terjadi diantaranya: ketersediaan makanan yang cocok dan mudah didapatkan, pertumbuhan lambat, jarak rematurasi yang panjang/lama, sulit memijah dalam wadah budidaya, dan mudah stres. Pada sebagian besar spesies yang didomestikasi akan menunjukkan plastisitas/kelenturan tingkah laku yang dapat membuatnya mampu beradaptasi dalam wadah budidaya dan pada lingkungan yang berbeda dengan habitat alaminya (Driscoll et al., 2009).

\section{FAKTOR PENDUKUNG PENGEMBANGAN SUMBERDAYABELIDA}

Dalam pemetaan kekuatan komoditas yang merupakan gambaran kriteria yang mempengaruhi suatu komoditas, dimana di dalamnya terdiri atas kriteria pemasaran, sumber benih, teknik budidaya, dampak terhadap pengembangan UKM dan agribisnis, institusi pengembang, dampak terhadap lingkungan serta keunggulan daerah, diketahui bahwa belida sebagaimana komoditas lain seperti udang galah, memiliki kekuatan dari sisi kriteria pemasaran (Sukadi et al., 2011). Dalam perkembangannya, selain kriteria pemasaran, keberadaan belida sebagai komoditi unggulan daerah serta dampaknya terhadap perkembangan UKM menjadi dasar bahwa komoditas belida "cukup" potensial untuk dikembangkan (Gambar 5). Sementara kelemahan pengembangan terletak pada sumber benih, teknik budidaya dan dampak terhadap lingkungan.

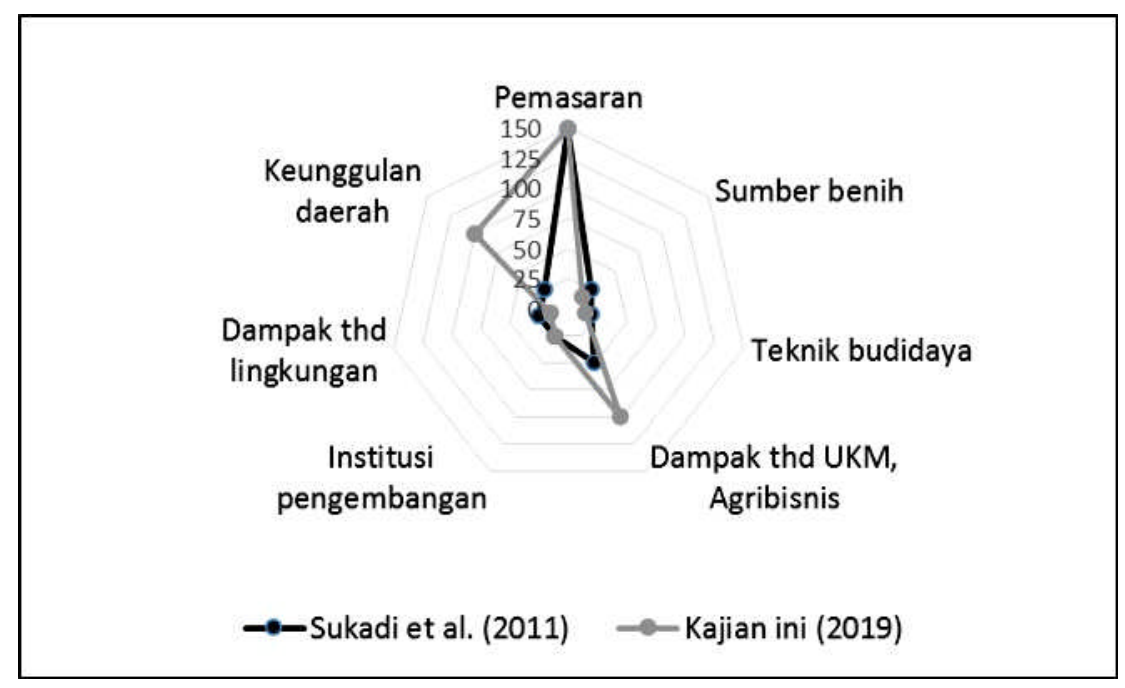

Gambar 5. Pemetaan kekuatan komoditas belida.

Figure 5. Mapping the strength of clown knifefish commodities.

Terkait sumber benih, terdapat BBI yang dikelola oleh pemerintah daerah tingkat I Riau, yaitu BBI sentral, dan BBI lokal yang dikelola oleh pemerintah daerah tingkat II. Di tingkat I Propinsi Riau terdapat 3 BBI, yaitu BBI Pantai Rupat, BBI Sei Tibun dan Unit pendederan. Di Tingkat II terdapat $2 \mathrm{BBI}$, yaitu BBI Bangkinang dan BBI Sei Sipungguk yang berada di bawah kewenangan Dinas Perikanan Kabupaten Kampar. Produk BBI antara lain patin, lele, mas, nila dan gurame. Di sekitar BBI telah berkembang pula kolam masyarakat sejak tahun 1987. Produksi budidaya umumnya mencapai 50 ton/hari termasuk dari usaha keramba seluas $4.000 \mathrm{Ha}$. Pemfokusan salah satu BBI sebagai penghasil benih belida untuk restocking dan budidaya merupakan langkah yang perlu dilakukan. Walaupun dalam kenyataannya Pemda setempat sudah menyediakan sarana di BBI Bangkinang (berupa 2 unit kolam pembesaran) dan BBI Sipungguk.

Di samping sarana pembenihan, terdapat mekanisme pasar yang sampai dengan saat ini turut mendukung upaya perlindungan belida secara alami. Harga ikan belida dari penangkapan alam umumnya berkisar antara Rp. 80-90 ribu per kg (di atas harga jelawat, baung, gabus dan lais, namun di bawah harga 
tapah) dengan harga tertinggi adalah yang berukuran besar. Kelas belida di pasaran meliputi: $A=>2 \mathrm{~kg}$ (harga tertinggi), $B=1-2 \mathrm{~kg}$ (harga menengah), $\mathrm{C}=$ $<1 \mathrm{~kg}$ (harga paling rendah). Rantai pasar yang terjadi pada komoditas belida di Kabupaten Kampar, Riau melibatkan pengumpul/pengepul lokal yang menghubungkan antara nelayan dengan pembeli yang berasal dari dalam atau luar kota. Mekanismenya dengan penjualan di pasar ikan atau yang dijemput langsung ke sentra nelayan.

Selain ukuran tangkap yang disepakati tersebut, kawasan konservasi juga berkontribusi terhadap keberlanjutan sumber daya ikan belida. Terdapat kawasan penyokong sumber daya ikan di Propinsi Riau, yaitu kawasan konservasi berbentuk lubuk larangan. Terdapat 2 lubuk larangan, yaitu Lubuk Larangan Indarung (Kabupaten Kuantan Singingi) dan Lubuk Larangan Sungai Sebayang (Kabupaten Kampar) (Kartamihardja et al., 2016). Sebanyak 24 desa di Kecamatan Kampar Kiri Hulu telah memiliki rata-rata dua titik lubuk larangan, dengan rata-rata panjang setiap titiknya adalah 200 meter, diantaranya Desa Gema, Tanjung Belit, Tanjung Batu Sanggan, Belit Selatan, Muara Bio, dan Tanjung Beringin, Gaja Bertalut, Aur Kuning, Tarusan, Subayang Jaya/Salo, Pangkalan Serai, Kota Lama, Ludai, Dua Sepakat, Tanjung Karang, Pangkalan Kapas, Batu Sasak, Sungai Santi, Bukit Bitung, Danau Sentul, Kebun Tinggi, Tanjung Permai, Lubuk Bigau dan Deras Setajak. Pembukaan lubuk larangan berlangsung pada musim kemarau saat air surut, yaitu sekitar bulan Juni atau Juli.

Selain lubuk larangan, terdapat suaka perikanan di Propinsi Riau yaitu danau oxbow Bakuok, yang merupakan danau tapal kuda yang terbentuk dari pemutusan aliran Sungai Kampar. Penetapan danau ini sebagai suaka perikanan berdasar pada hukum adat Ma'uwo (bulan boleh menangkap ikan, yaitu September) dan Adat Kenagarian Tambang (pihak yang mengatur waktu, cara dan pemanfaatan ikan). Sebagai kawasan suaka adat, Danau Bakuok dijaga secara kolektif oleh masyarakat (PRPT, 2007; Amri \& Prasetyo, 2008; Umar et al., 2012). Selain sungai, rawa banjiran dan danau yang menjadi kawasan konservasi berupa suaka perikanan, beberapa bagian dari Waduk Koto Panjang dinyatakan layak sebagai suaka perikanan.

\section{STRATEGI PENGELOLAAN}

Upaya untuk melestarikan belida dapat dilakukan dengan pengendalian penangkapan melalui penegakan hukum perlindungan terhadap belida yang dipayungi aturan Permen LHK nomor 20 tahun 2018, menjaga mekanisme pasar melalui pengaturan harga bagi ukuran belida yang boleh ditangkap, mempertahankan kearifan lokal berupa lubuk larangan melalui penguatan aspek legal keberadaannya, serta upaya budidaya.

Arahan pengelolaan dari sisi budidaya terlihat relatif mudah dilaksanakan. Mengingat pengendalian penangkapan di alam relatif sulit dilakukan dan laju degradasi sumber daya ikan belida dan kerusakan lingkungan yang tersirat lebih cepat dibandingkan pemulihannya. Peran para pembudidaya dan pemulia dalam memanfaatkan dan meningkatkan produksi/ produktivitas sumberdaya ikan yang tersedia merupakan salah satu kunci keberhasilan pemanfaatan secara optimal dan pelestarian sumberdaya genetik yang berkelanjutan. Sebagai contoh, terdapat program pengembangan sumber daya genetik untuk menunjang diversifikasi usaha budidaya yang sudah berhasil dilakukan pada 40 spesies komoditas ikan (Gustiano, 2006), dengan spesies asli meliputi 32 spesies (Nugroho, 2002; Sugama, 2006), 22 spesies diantaranya adalah ikan air tawar (Gustiano, 2006).

Pengembangan teknologi pendeteksian tingkat keragaman genetik dan informasi sifat serta manfaat di dalamnya memungkinkan dalam melakukan konservasi di luar habitat (ex-situ). Konservasi ex-situ dilakukan untuk tujuan pemulihan kondisi spesies di habitat alamnya. Konservasi ex-situ sumber daya genetik, selain untuk tujuan pemulihan juga dibutuhkan untuk pemanfaatan secara optimal tanpa harus terusmenerus melakukan penelitian ke situs alaminya atau merusak keanekaragaman hayati di alam. Oleh karenanya perlindungan sumber daya genetik ikan melalui konservasi ex-situ sama pentingnya dengan konservasi in-situ. Pengembangan sumber daya genetik lokal layak dikembangkan untuk mempertahankan identitas suatu daerah selain tujuan untuk kepentingan produksi dan pelestarian ikan-ikan favorit dari kepunahan, sebagaimana telah dilakukan pada ikan Batak di Sumatera Utara, Belida di Sumatera Selatan, Nilem/Kancra/Tambra di Jawa Barat, Sidat di Sulawesi, Cherax di Papua, Jelawat di Kalimantan (Gustiano, 2006; Aisyah et al., 2019).

Upaya pemulihan sumber daya ikan belida telah diinisiasi sejak disadarinya bahwa sumber daya ini mengalami penurunan populasi (Kottelat et al., 1993), diantaranya translokasi dan restocking dari dan ke Sungai Kampar (Wibowo et al., 2010). Upaya ini kemudian diperbarui dengan penerapan teknologi pen system yang diinisiasi Pusat Riset Perikanan tahun 2020 (walaupun pelaksanaannya tertunda karena kebijakan anggaran terkait kondisi Pandemi COVID-19). 
Strategi pemulihan yang direkomendasikan dalam kajian ini dititik-beratkan pada budidaya untuk mempercepat peningkatan produksi dan pelestarian sumber daya plasma nutfah ikan belida, melalui optimalisasi peran Balai Benih Ikan (BBI) sebagai sarana pemerintah untuk menghasilkan benih ikan dan untuk membina usaha pembenihan ikan rakyat.

Langkah jangka pendek yang bisa diakukan segera adalah mempersiapkan BBI sebagai tempat pembudidayaan belida, persiapan juga termasuk kolam induk dan kolam pemijahan alami, mengumpulkan induk belida, mempersiapkan hatchery pendederan larva, mempersiapkan kolam pembesaran khusus benih belida. Evaluasi terhadap kondisi terkini BBI Sipungguk kaitannya dengan upaya pelestarian belida adalah perlunya memperdalam kolam induk.

\section{KESIMPULAN DAN REKOMENDASI Kesimpulan}

Kontribusi perikanan belida terhadap total produksi perikanan perairan darat baik secara lokal (Riau) maupun nasional adalah relatif kecil, namun sampai dengan saat ini kebutuhan pasar dan industri lokal Riau hingga luar Riau masih bisa dipenuhi. Walaupun jika dilihat dari sediaan induk di alam rendah dan tingkat pemanfaatan yang tinggi. Di sisi lain, status belida saat ini bukan merupakan komoditas budidaya sebagaimana komoditas lain. Budidaya belida masih dalam tahap pemantapan dan penguasaan teknologi pemijahan. Beberapa faktor pendukung pelestarian belida antara lain adanya aturan pendukung perlindungan satwa, terdapat mekanisme pasar yang baik (harga tinggi untuk belida ukuran besar), keberadaan lubuk larangan (area konservasi), upaya pembesaran, penebaran kembali, pencanangan program pengembangan budidaya, serta perekayasaan melalui peningkatan produktivitas benih dan produksi calon induk generasi pertama (G1). Strategi pengelolaan yang diusulkan antara lain melakukan konservasi di luar habitat (ex-situ) untuk perlindungan sumber daya genetik. Mengoptimalkan Balai Benih Ikan (BBI) untuk menghasilkan benih ikan dan membina usaha pembenihan ikan rakyat.

\section{Rekomendasi}

Berdasarkan keberadaan dan perkembangan teknologi budidaya yang sudah ada, maka beberapa hal yang dapat dijadikan rekomendasi antara lain:

- Pemerintah daerah dibantu oleh pemerintah pusat menyediakan kawasan budidaya belida yang dilengkapi dengan perijinan kawasan satu pintu dan sertifikasinya,
Perbaikan sistem pendataan agar lebih menggambarkan kondisi nyata sumber daya ikan belida di alam,

- Menambah jumlah wilayah konservasi dan memasukannya ke dalam rencana tata ruang dan kewilayahan,

- Mengoptimalkan Balai Benih Ikan (BBI) untuk menghasilkan benih ikan belida dan untuk membina usaha pembenihan ikan rakyat.

\section{PERSANTUNAN}

Penelitian ini dibiayai oleh Kementerian Kelautan dan Perikanan melalui DIPA Pusat Riset Perikanan tahun anggaran 2019. Terima kasih disampaikan kepada Dinas Perikanan Kabupaten Kampar, Riau atas pendampingan selama pelaksanaan kegiatan. Prof. Dr. Endi S. Kartamihardja dan Balai Riset Pemulihan Sumberdaya Ikan-Jatiluhur atas informasi pendukung terkait belida.

\section{DAFTAR PUSTAKA}

Adjie, S., \& Utomo, A.D. (1994). Aspek biologi ikan belida di perairan sekitar Lubuk Lampam Sumatera Selatan. Prosiding Seminar Penyusunan, Pengolahan, dan Evaluasi Hasil Penelitian Perikanan Perairan Umum.

Adjie, S., Husnah., \& Gaffar, A.K. (1999). Studi biologi ikan belida Notopterus chitala di daerah aliran sungai Batanghari Propinsi Jambi. J. Lit. Perik. Ind. 5(1), 38-43. DOI: http://dx.doi.org/10.15578/ jppi.5.1.1999.38-43

Aisyah. (2019). Karakteristik dan potensi ekosistem KPP PUD 438. Dalam: Potensi pengembangan dan pemanfaatan perikanan KPP PUD 438 (PP.623). AMaFRaD Press. Jakarta. P. 241.

Aisyah, Husnah, Susanto, K., Hidayah, T., \& Mersi. (2019). Pemanfaatan dan pengelolaan perikanan rawa di KPP 435: Kalimantan Tengah. Laporan survey lapangan. P. 5.

Aisyah, Triharyuni, S., \& Fahmi, Z. (2018). Variasi hidro-klimatik musiman kaitannya dengan tangkapan ikan per unit upaya (CPUE) di Waduk Malahayu. Prosiding Seminar Ikan ke-10. P. 10.

Amri, K., \& Prasetyo, D. (2008). Pengelolaan suaka perikanan Danau Bakuok Kabupaten Kampar, Riau. BAWAL, 2(3), 107-112. DOI: http:// dx.doi.org/10.15578/bawal.2.3.2008.107-112 
Azadi, M.A., Mahamood, N., \& Shafi, M. (1994). Studies on the age and growth of Chital, Notopterus chitala (Ham.) from the Kaptai Reservoir, Bangladesh. Chittagong Univ. Stud. 18(2), 197-205.

BAPPEDA \& BPS. (2006). Riau dalam angka tahun 2006. BAPPEDA Propinsi Riau \& Badan Pusat Statistik Propinsi Riau. P. 432.

BAPPEDA \& BPS. (2007). Riau dalam angka tahun 2007. BAPPEDA Propinsi Riau \& Badan Pusat Statistik Propinsi Riau. P. 437.

BPS. (2008). Riau dalam angka tahun 2008. Badan Pusat Statistik Propinsi Riau. P. 418.

BPS. (2009). Riau dalam angka tahun 2009. Badan Pusat Statistik Propinsi Riau. P. 428.

BPS. (2010). Riau dalam angka tahun 2010. Badan Pusat Statistik Propinsi Riau. P. 426.

BPS. (2011). Riau dalam angka tahun 2011. Badan Pusat Statistik Propinsi Riau. P. 432.

BPS. (2012). Riau dalam angka tahun 2012. Badan Pusat Statistik Propinsi Riau. P. 438.

BPS. (2013). Riau dalam angka tahun 2013. Badan Pusat Statistik Propinsi Riau. P. 446.

BPS. (2014). Riau dalam angka tahun 2014. Badan Pusat Statistik Propinsi Riau. P. 446.

BPS. (2015). Riau dalam angka tahun 2015. Badan Pusat Statistik Propinsi Riau. P. 468.

Cholik, F., Jagadraya, A.G., Poernomo, R.P., \& Jauji, A. (2005). Akuakultur tumpuan harapan masa depan bangsa. Masyarakat Perikanan Nusantara dan Taman Akuarium Air Tawar. Jakarta. P. 415.

Dewi, R.R.S.P.S., Nugroho, E., Subagja, J., \& Priono, B. (2019). Domestikasi ikan belida langka, Chitala lopis (Bleeker, 1851): pembenihan secara terkontrol di luar habitat alami. Media Akuakultur. 14(2), 73-81. DOI: http://dx.doi.org/10.15578/ ma.14.2.2019.73-81

Diskanlut Riau. (2015). Statistik perikanan tangkap. Bagian dari laporan bagian pendataan.

DJPT. (2015). Statistik perikanan tangkap nasional. Buku statistik. Direktorat Jendral Perikanan Tangkap-Kementerian Kelautan dan Perikanan.
Driscoll, C.A., MacDonald, D.W., \& O'Brien, S.J. (2009). From wild animals to domestic pets, an evolutionary view of domestication. Proceedings of the National Academy of Sciences of The United States of America, 106: 9971-9978.

Fazli, M., Efawani., \& Yuliati. (2013). Types and Density of Aquatic Plant in Rengas Lake, Buluh Cina Village, Siak Hulu Sub-Regency, Kampar Regency, Province of Riau. P. 12.

Froese, R., \& Pauly, D. (2013). Chitala chitala (Hamilton, 1822) . [online] India Biodiversity Portal,Species Page: \{name of species field\} Available at: https://indiabiodiversity.org/biodiv/ species/show/232028 [Accessed date Dec 24, 2020].

Gustiano, R. (2006). Kajian teknis dan sosioekonomis pengelolaan berkelanjutan sumber daya genetik ikan. Lokakarya Nasional Pengelolaan dan Perlindungan Sumber Daya Genetik di Indonesia. 48-53.

Haniffa, M.A., Arockia-Raj, A.J., Nagarajan, M., Perumalsamy, P., Seetharaman, S., \& Singh, S.P. (2004). Natural breeding in captivity: a possibility for conservation of threatened freshwater featherback Notopterus notopterus. Aquaculture Asia. 9 (1), 3638. http://aquaticcommons.org/id/eprint/202.

Haryono. (2008). Potensi ikan belida dan upaya konservasinya. Fauna Indonesia. 8 (2), 5-8.

Isroni, W. (2019). Belida Jawa (Notopterus notopterus): ikan lokal Sungai Brantas, kondisi terkini dan tantangan ke depan. https:// fpk.unair.ac.id/belida-jawa-notopterus-notopterus-ikanlokal-sungai-brantas-kondisi-terkini-dan-tantangankedepan/, diakses pada 24 Desember 2020.

Kartamihardja, E.S., Prahoro, R.P., Sugianti, Y., Warsa, A., Hedianto, D.A., Sukamto., \& Purnama, P. (2016a). Ecological assessment untuk restocking belida di perairan Propinsi Riau. Artikel hasil penelitian. Balai Riset Pemulihan dan Konservasi Sumberdaya Ikan. P. 1.

Kartamihardja, E.S., Aisyah., Atminarso, D., Budi, E. K., Fredy., \& Purnama, P. (2016 $)$. Ecological assessment untuk monitoring kawasan yang mengalami penurunan stok belida (depleated stock). Laporan survey lapangan, bagian dari penelitian yang didanai DIPABalai Riset Pemulihan dan Konservasi Sumberdaya Ikan. 24-30 Juli 2016. 
Kottelat, M., Whitten, A.J., Kartikasari, S.N., \& Wirjoatmodjo, S. (1993). Freshwater fishes of Western Indonesia and Sulawesi. Periplus Editions, Hong Kong. P. 221.

Kottelat, M., Whitten, T. (1996). Freshwater biodiversity in Asia: special reference to fish. The World Bank. Washington DC.

Kristanto, A.H., \& Subagja, J. (2010). Respon induk ikan belida terhadap hormon pemijahan. Prosiding Forum Inovasi Teknologi Akuakultur: 113-116. http://ejournal-balitbang.kkp.go.id/index.php/fita/ article/view/6353.

Lestari, M. (2010). Aspek biologi reproduksi ikan belida (Chitala lopis) di Daerah Aliran Sungai Kampar, Provinsi Riau. Skripsi. Institut Pertanian Bogor. P. 73.

Merona, B., \& Vigouroux, R. (2006). Diet changes in fish species from a large reservoir In South America and their impact on the trophic structure of fish assemblages (Petit-Saut Dam, French Guiana). Annales de Limnologie. 42, 53-61. h t t p s : / / doi.org/10.1051/limn/2006006.

Mitra, A., Mukhopadhyay, P.K., Homechaudhuri, S. (2018). An overview of biology and culture potentials of Humped Featherback Chitala chitala (Hamilton, 1822)-a new candidate for aquaculture diversification. Reviews in Fisheries Science \& Aquaculture, DOI: 10.1080/23308249.2018.1437118. p 10.

Nugroho, E. (2002). Pemanfaatan dan pelestarian plasma nutfah ikan untuk meningkatkan produktifitas perikanan budidaya. Warta Penel. Perik. Indon, 8 6-13.

Nugroho, E., Dewi, R.R.S.P.S., \& Aisyah. (2019a). Pelestarian ikan belida melalui pemanfaatan sumberdaya genetik lokal. Policy brief. P. 4.

Nugroho, E., Dewi, R.R.S.P.S., Subagja, J., \& Priono, B. $\left(2019^{\mathrm{b}}\right)$. Keragaman genetic dan karakter biometric ikan belida (Citala lopis, Bleeker 1851) budidaya asal Sungai Kampar, Riau. Jurnal Riset Akuakultur. 14(1), 1-8. DOI: http://dx.doi.org/ 10.15578/jra.14.1.2019.1-8.

Nurmaini, Nurdin, S., \& Yuliati. (2012). A study of density and closeness of water plant in the Segati River, Langgam District, Pelalawan Regency, Riau. P. 11.

PRPT. (2007). Riset kebijakan pemanfaatan dan konservasi keanekaragaman hayati ikan. Pusat Riset Perikanan Tangkap. Laporan akhir. P. 70.
Santoso, L. (2009). Biologi reproduksi ikan belida (Chitala lopis) di Sungai Tulang Bawang, Lampung. Berkala Perikanan Terubuk. 37(1), 38-46. DOI: http://dx.doi.org/10.31258/terubuk.37.1.\%25p

Sarkar, U.K., Deepak, P.K., Negi, R.S., Singh, S.P., \& Kapoor, D. (2006). Captive breeding of endangered fish Chitala chitala (HamiltonBuchanan) for species conservation and sustainable utilization. Biodivers. Conserv. 15: 3579-3589. DOI:10.1007/s10531-004-2935-6.

Setijaningsih, L., Subagja, J., Radona, D., Pantjara, B., Kristanto, A.H., \& Widyastuti, Y.R. (2018). Performa pemijahan ikan belida (Notopterus chitala) melalui induksi hormon HCG dan LHRH. Jurnal Riset Akuakultur, 13 (2), 2018, 115-122. DOI: http://dx.doi.org/10.15578/jra.13.2.2018.115-122

Funge-Smith, S., Briggs, M. \& Miao, W. (2012). Regional overview of fisheries and aquaculture in Asia and the Pacific 2012. Asia-Pacific Fishery Commission, FAO Regional Office for Asia and the Pacific. RAP Publication 2012/26. 139 pp.

Sodsuk, P.K. and Sodsuk, S. 2000. Genetic diversity of featherback fish in Thailand. Kasetsart J. (Nat. Sci.), 34, 227-239.

Srivastava, S.M., Srivastava, P.P., Dayal, R., Pandey, A.K., \& Singh, S.P. (2010). Induced spawning of caprive stock of threatened bronze featherback, Notopterus notopterus, for stock improvement and conservation. J. Appl. Biosci., 36 (2), 144-147. http:/ /krishi.icar.gov.in/jspui/handle/123456789/5009.

Srivastava, S.M., Gopalakrishnan, A., Singh, S.P., \& Pandey, A.K. (2012). Embryonic and larval development of threatened bronze featherback Notopterus notopterus (Pallas). J. Exp. Zool. India, 15(2), 425-430. DOI: 10.13140/ RG.2.2.22930.15040

Sugama, K. 2006. Perbaikan mutu genetik ikan untuk mendukung pengembangan perikanan budidaya. Buku Orasi Pengukuhan Professor Riset. P. 77.

Sukadi, M.F., Widiyati, A., Nugroho, E., Komarudin, O., Azwar, Z.I., Prihadi, T. H., \& Huwoyon, G.H. (2011). Analisis komoditas ikan local di Kalimantan Tengah: dalam Analisis Kebijakan Pembangunan Perikanan Budidaya 2011. pp. 213-231.

Sukemi., Hendrik., \& Hendri., R. (2016). Pemasaran ikan air tawar di Pasar Teratak Buluh Kecamatan 
Siak Hulu Kabupaten Kampar Provinsi Riau. P. 12.

Sunarno, M.T.D. (2002). Selamatkan plasma nutfah ikan belida. Warta Penelitian Perikanan Indonesia. 8(4), 2-6.

Sunarno, M.T.D., \& Syamsunarno, M.B. (2015). Pengaruh naungan terhadap pematangan gonad dan pemijahan ikan belida (Chitala lopis) di kolam rawa. Jurnal Ilmu Pertanian dan Perikanan. 4(1), 71-77.

Suprapto, Y. 2018. https://www.mongabay.co.id/2018/ 12/16/ikan-belida-makin-langka-mengapa/, diakses tanggal 24 Desember 2020.

Tabloid Desa. (2017). Pemkot Palembang akan gencarkan budidaya ikan belida. Artikel diunduh pada https://tabloid-desa.com/pemkot-palembangakan-gencarkan-budidaya-ikan-belida/, pada 11 September 2020.

Tamayo, M.G., \& Bunal, R.V. 2018. Utilization of knifefish (Chitala ornata) in the development of value added products: An input for sustainable food production. Posters \& Accepted Abstracts on $9^{\text {th }}$ International Conference on Fisheries \& Aquaculture.

Teletchea, F., \& Fontaine, P. (2014). Levels of domestication in fish: implications for the sustainable future of aquaculture. Fish and Fisheries. 15, 181-195. https://doi.org/10.1111/ faf.12006

Umar, C., Kartamihardja, E. S., Fahmi, Z., Prianto, E., Aisyah, Zulfia, N., \& Racmawati, P. F. (2012). Penelitian kebijakan pengelolaan sumberdaya ikan di perairan Danau di Sumatera. Laporan akhir, Puslit Pengelolaan Perikanan dan Konservasi Sumberdaya Ikan. P. 74.
Vidthayanon, C., (2005). Thailand red data: fishes. Office of Natural Resources and Environmental Policy and Planning, Bangkok, Thailand. P. 108

Wibowo, A., Affandi, R., \& Rahmah, S. (2010ª). Kebiasaan makanan ikan belida (Chitala lopis Bleeker, 1851) di daerah aliran Sungai Kampar, Provinsi Riau. Prosiding Seminar Nasional Ikan VI, 79-89.

Wibowo, A., Affandi, R., Soewardi, K., Sudarto. $\left(2010^{\mathrm{b}}\right)$. Pengelolaan sumber daya ikan belida (Chitala lopis) di Sungai Kampar, Provinsi Riau. Jurnal Kebijakan Perikanan Indonesia. 2(2), 7989. DOI: http://dx.doi.org/10.15578/ jkpi.2.2.2010.79-89

Wibowo, A. (2012). Struktur genetic populasi ikan belida (Chitala lopis, Bleeker 1851) di Waduk Koto Panjang. BAWAL. 4(1), 53-58. DOI:http:// dx.doi.org/10.15578/bawal.4.1.2012.53-58

Wibowo, A., \& Marson. (2012). Fenomena plastisitas fenotipik ikan belida (Chitala lopis) di Sungai Kampar, Riau. BAWAL. 4(3), 195-204. DOI: http:/ /dx.doi.org/10.15578/bawal.4.3.2012.195-204

Wibowo, A. (2014). Barcoding ikan belida (Chitala lopis) berdasarkan gen Cytochrome Oxidase Subunit I (COI) DNA mitokondria. Prosiding Seminar Nasional Tahunan XI Hasil Penelitian Perikanan dan Kelautan, 227-235.

Yanwirsal, H., Bartsch, P., \& Kirschbaum. (2017). Reproduction and development of the Asian bronze featherback Notopterus notopterus (Pallas, 1769) (Osteoglossiformes, Notopteridae) in captivity. Zoosyst. Evol. 93(2), 299-324. 